\title{
BEING - AND STAYING - FAMOUS IN 19TH-CENTURY SPAIN: BALDOMERO ESPARTERO AND THE BIRTH OF POLITICAL CELEBRITY*
}

\author{
ADRIAN SHUBERT \\ York University \\ adriansh@yorku.ca
}

(Recepción: 06/06/2014; Revisión: 31/07/2014; Aceptación: 29/09/2014; Publicación: 26/11/2015)

1. Family traditions.-2. Images.-3. Writing to Espartero.-4. Conclusion.-

5. BIBLIOGRAFÍA

\begin{abstract}
This article argues that Baldomero Espartero remained widely famous and popular for decades after the end of his active political career and his political failures. While the initial Espartero cult was created from above following his heroic victory at Lu-chana and consolidated after the Embrace of Vergara, the maintenance of the cult through the 1860s was largely driven from below. The article uses a range of sources: oral and family traditions, cheap books and images and, above all letters written to Espartero, to explore what was the first case of modern political celebrity in Spain.
\end{abstract}

Key words: Espartero; hero; popular culture; fame; celebrity.

$\left(^{*}\right)$ Research for this paper was carried out with an Insight Grant from the Social Sciences and Humanities Research Council of Canada (SSHRC). I want to thank Isabel Burdiel, Antonio Cazorla-Sánchez, and Oscar Rodríguez Barreira for their comments on earlier versions of this article. 


\title{
SER - Y SEGUIR SIENDO- FAMOSO EN LA ESPAÑA DEL SIGLO XIX: BALDOMERO ESPARTERO Y EL NACIMIENTO DE LA CELEBRIDAD POLÍTICA
}

\begin{abstract}
RESUMEN
Este artículo sostiene que Baldomero Espartero era muy famoso y popular décadas después del final de su carrera política activa. Mientras que el culto original de Espartero fue creado desde arriba después de su victoria en Luchana y se consolidó con el Abrazo de Vergara, el mantenimiento del mismo durante la década de 1860 tuvo una naturaleza eminentemente popular. Este artículo usa varios tipos de fuentes como las orales, tradiciones familiares, canciones y nanas, libros e imágenes en ediciones populares y, sobre todo, cartas escritas a Espartero. Todas ellas ayudan a explicar el que fue el primer caso de celebridad política en España.
\end{abstract}

Palabras clave: Espartero; héroe; cultura popular; fama, celebridad.

$* \quad * \quad *$

Within days of the «Gloriosa» that swept Isabel II from the throne in September 1868, Baldomero Espartero became a frequently-invoked symbol. He was a prominent part of the «fiesta revolucionaria» that spread across the country following the fall of the queen and the transfer of power to the revolutionary Juntas. A portrait of Espartero was exhibited on the balcony of the Huelva town hall as if to preside over the three days of celebration organized by the ayuntamiento; in Barcelona, his bust graced the Diputación building and a huge portrait was placed on the façade of the city hall, while in Valladolid, the first day of celebrations was, according to Angel Bellogín, a member of the revolutionary Junta, «dedicado al ilustre duque de la Victoria» (1). Nor was it just the new revolutionary authorities who invoked Espartero's name and image. Along with sheet music for Prim: Himno nacional para canto y piano and the liberal classic, the Himno de Riego, music stores were advertising music for the Himno de Espartero (2). And in the new world of unprecedented freedom to publish newspapers and pamphlets and perform plays, Espartero figured prominently (3).

During the two year interinidad that extended from the victory of the revolution until the decision of the Cortes Constituyentes, in November 1870, to

(1) De la Fuente Monge (2000): 93-4; Bellogín (1993): 329.

(2) La Correspondencia de España, 8 october, 1868, La Iberia, 6 oct. 1868.

(3) On Espartero in the theatre, see De la Fuente Monge (2013); CAire-Mérida (2006). On Espartero in pamphlet literature and the press see SÁEz Miguel (2011). 
offer the throne to Amadeo of Savoy, Espartero, who had refused to assume any role in the revolution and who limited his interventions to calling on his supporters to respect the new authorities, emerged as a popular candidate to become the head of state, either as king in a new-style democratic monarchy or as president of a Spanish republic. This situation was captured in a flyer entitled Espartero, rey o presidente which was circulating on the streets of Barcelona late in 1868. Beneath a crude drawing of a seated Espartero being offered a scroll that reads «REPUBLICA FEDERAL» from one side and a crown on the other, there is a dialogue in which «Monárquicos» and «Republicanos» take turns explaining why they want him as head of state (4). And when the new Constitution of 1869 proclaimed Spain a monarchy and the government set out to find a ruler for the throne, Espartero emerged as a popular candidate: between November 1869 and June 1870 some 268 petitions, signed by at least 100,000 people, flooded into the parliamentary mail room (5). According to historian and contemporary Antonio Pirala, «[1]a candidatura de Espartero fue indudablemente la más popular. Ninguna se proclamó en más folletos y artículos. Ni se produjo las manifestaciones tan numerosas como espontáneas que en Madrid y otras capitales se celebraron» (6).

Espartero was an active public figure for fewer than nine years: between the Battle of Luchana in December 1836 and the end of his Regency in July 1843, and again during the Bienio Progesista of 1854 to 1856. At the time of the «Gloriosa», all this was long in the past and, in any case, Espartero's political life had been less than a success; even many Progressives had joined the conspiracy that forced him from the Regency in 1843; he disappointed many in the crisis of July 1856, and he remained a divisive figure among them through the 1860 s. By 1868 , he was 75 years old. He had spent the previous twelve years living quietly in Logroño, and although he remained the titular head of the Progresistas until 1864 he was far removed from active political engagement or the political limelight. Espartero should have been yesterday's man but clearly this was not the case.

Indeed, he remained an important point of reference into the 1870s. Throughout the rest of the Sexenio Democrático he was a kind of «necessary man». Whenever there was a political crisis, Espartero was inevitably mentioned as the solution. And in a curious, and perhaps unique, inversion, in the 1870s two successive Spanish kings, Amadeo I (1870-1873) and Alfonso XII (18741885), felt it necessary to appropriate Espartero's fame on behalf of their shaky legitimacy.

Amadeo of Savoy, the younger son of King Victor Emmanuel II of Italy, was elected king by the Cortes Constituyentes in November 1870. In September

(4) Biblioteca de Catalunya, F. Bon. 2085.

(5) Legajo 229, Archivo del Congreso de los Diputados, Madrid.

(6) Pirala (1875-79): V. 3, 402. 
1871, he traveled to Logroño to visit Espartero, spending almost his entire stay in Espartero's home. Four months later, he took the exceptional step of naming Espartero Prince Vergara; only the second time someone other than the son or daughter of a reigning monarch was given the rank of prince (7). Alfonso XII, who came to the throne in 1875 following the military coup that ended the sortlived and chaotic First Republic, visited Espartero three times and confirmed the title Prince of Vergara. The first visit came in February 1875, only six weeks after Alfonso had been proclaimed king. Antonio Cánovas del Castillo, the Prime Minister and the man who had engineered Alfonso's return, considered it so important that, in order not to «privar a la Nación de los detalles interesantes» he had a supposedly confidential letter describing the visit published in the official Gaceta de Madrid. After hearing that Alfonso had refused to accept the Gran Cruz de San Fernando, Espartero replied that as Alfonso had been the first Spanish king since Felipe V to lead his troops into battle, he deserved the Gran Cruz and offered to pin on the king's chest «la banda que ha llevado este veterano en cien combates, ganada derramando su sangre por la integridad de la Patria, por su independencia, por vuestros antepasados, y por las libertades públicas» before reminding him that a constitutional monarch must «ser justo y fiel custodio de las libertades públicas». The letter concluded by highlighting the importance of «el abrazo del más anciano y calificado caudillo de nuestra libertad y del más joven y animoso depositario de la Monarquía legítima». The second visit came just days after Alfonso had ended the Second Carlist War, becoming the new «Pacificador de España», the unofficial title by which so many Spaniards referred to Espartero (8). The final visit was in October 1878, when the recentlywidowed king came to share his mourning with the recently-widowed Espartero.

Why was this so? What were the mechanisms that allowed Espartero to retain his fame for so many years after his public life had come to an end? (9) Like that of his contemporary, Giuseppe Garibaldi, with whom he was occasionally compared, Espartero's initial fame was due to the kind of «political and rhetorical strategy» so deftly described by Lucy Riall (10). The Espartero cult

(7) On Amadeo's visit see Bermejo Martín (2000): 190-2, 295-9. The other case was Manuel Godoy, whom Carlos IV named Príncipe de la Paz in 1805.

(8) Bermejo Martín (2000): 192-3; Gaceta de Madrid, 14 February 1875. On January 10, 1875, mere days after Alfonso was proclaimed king, Espartero sent him a letter: «Aseguro a VM que tendra en mi su fiel servido y en la actualidad solo dese ver a todos los liberales unidos a VM para que podamos devolver la paz y la ventura a nuestra madre patria». Espartero Archive (20) 1875-08. Alfonso had Espartero's letter published in the Gaceta. There is some evidence the tactic was effective. One of the congratulatory letters Espartero received on his saint's day in 1875 noted the «mucho que se ha divulgado el acto de condecorar VE al Rey con la banda de la Gran Cruz de San Fernando». Espartero Archive (26), 1871-486.

(9) The classic study of fame is Braudy (1997). Also Berenson and Gioli (2010) and MORGAN (2011). For a recent interpretation which sees celebrity as a product of modernity created and diffused between 1750 and 1850, see LILTI (2014).

(10) Riall (2007): 13. 
was created from scratch in a very short time. Before the Battle of Luchana on December 24, 1836 he was known only to his family, friends and comrades. A few days later he was a national hero. The event was «un verdadero drama romántico», to use Luis Garrido Muro's description (11). On a snowy Christmas Eve, Espartero rose from the sickbed where his recurrent kidney stone problem had put him, and to the cry «iViva Isabel II y la libertad!» he led a cavalry charge across the Luchana bridge to relieve the city of Bilbao, which had been under Carlist siege for two months. At 8am on Christmas morning, to the pealing of church bells, Espartero led his troops into the city.

This was a crucial and unexpected victory, and liberal Spain «se volvió loco de alegría al saber la noticia». Espartero's dispatch was read in parliament and printed in a special issue of the official Gaceta. Progressive politician Joaquín María López gave a famous speech which, according to Nicolás Estévanez, «los entusiastas liberales de aquella generación que tuvo tantos vitores para Espartero... sabía de memoria» (12). There were special theatre performances and widely-supported subscriptions for the widows and orphans of the defenders of Bilbao. City after city named a street or square after the battle. On February 6, 1837, every church in Spain celebrated a special mass for those had died and priests discussed the battle in their sermons. The next month, Antonio García Gutiérrez's El sitio de Bilbao debuted in Madrid: it ended with a member of the militia shouting « $i$ Viva la libertad! ;Viva Espartero!», perhaps the first voicing of a pairing that would last decades.

Espartero was later named commander in chief and it was in this role that he brought the war to a successful conclusion with a negotiated peace - and the wonderfully theatrical «embrace of Vergara» - on August 31, 1839. News of the end of the war turned Madrid into «una completa fiesta durante dos semanas», and the rest of the country followed as soon as it heard (13). This was Espartero's peace and it made Espartero the most famous, admired, and beloved person in the country, the Pacificador de España as he came to be known. In the year following Vergara, Espartero reached «una altura desconocida para cualquier de sus contemporáneos. Medallas conmemorativas, procesiones con su retrato a cuestas, toda clase de obsequios, poemas en su honor, felicitaciones de todas las instancias, coronas de oro... Toda la nación parecía estar rendida a los pies de su pacificador». The Espartero cult touched even ordinary aspects of daily life: men adopted his «stubble» look and carried silver cigar cases with his image on them and children would be dressed «Espartero style» for special occasions (14).

(11) Garrido Muro (2012): 119. He even compares Luchana and Espartero de the Duque de Rivas' classic Romantic play, Don Alvaro, o la fuerza del destino. What follows is based on GARRIDO Muro: 115-8. See also DíAZ MARÍN (2006).

(12) ESTEVÁNEZ (1903): 53.

(13) GARRIDO MURO (2012): 15-23.

(14) Ibíd. 95-96, 564-65. 
That was 1840 . Soon after came the turmoil of his Regency, which split the Progressives, generated a fierce press campaign against him and ended in 1843 in a military revolt and exile (15). His return to power following the Revolution of 1854 was no less brief and no more successful, and after it he continued to be a divisive figure, especially among Progressives. In spite of all this, Espartero retained his fame and his following. In part this was due to the efforts of the branch of the Progressives, headed by Pascual Madoz and, until he decided that General Prim was a better bet, Victor Balaguer, which continued to see Espartero as their leader (16). But only in part. The Espartero cult had much greater reach than did the still notable-based political formations of Spanish liberalism. Espartero, like Garibaldi, was «genuinely 'popular' in that his appeal stretched beyond an elite intellectual readership and reached a broader literate public»and a not-so-literate public. The same kinds of «cheap and easily accessible textual and visible material» which fed the Garibaldi cult fed Espartero's. And the two cults were also similar in being «largely a collaborative effort» which the fans had a role in constructing (17). Finally, like Garibaldi, Espartero remained alive long after he retreated from active public life. Indeed both men retired to relatively remote locations: Garibaldi to Caprera and Espartero to Logroño. This long afterlife distinguished Espartero from other heroes of Spanish liberalism like Rafael de Riego and Juan Prim, both of whom gave their lives for the cause and could be made into secular saints in a way the long-lived Espartero could not (18).

The two cults were different in one significant respect: once it had been created, the survival of the Espartero cult was driven more from below than from above. It was manifested in cheap books and images, but the existence of these products was less a result of political programming than of market demand, itself the product of oral tradition, often at the family level. What follows uses a variety of sources, but especially the letters Espartero received from people from across Spain (19), to determine the mechanisms of Espartero's

(15) DíAz MARín (2008). This analysis is based on the press, so that the extent to which Espartero's image was «ruined» would be restricted to a rather narrow range of Spaniards.

(16) On Pascual Madoz see PARedes Alonso (1991), and on Victor Balaguer, PALOMÁs I MonCHOLí (2004). As one of the «'profesionales' en la órbita progresista», Balaguer played a major role in creating the cult of Prim during the War of Africa in 1859-1860, a cult which was created in much the same way as the original Espartero cult. See GARCÍA BALANYÀ (2002): 38.

(17) Riall (2007): On the importance of the consumer in constructing celebrity see BERENSON and GiOLI (2010):10-13 and MORGAN (2011): 99.

(18) HoRne (2004): 28. The same could be said, on the Moderado side of the liberal political spectrum, for «Nuestro joven héroe», Diego de León, the dashing general Espartero had executed in 1841 for participating in a failed coup against his Regency. The glorification of de León was accompanied by the vilification of Espartero. See GARCÍA SÁNCHEZ (2012) and ZOZAYA MONTES (2008): 166-176.

(19) There are, of course, limitations to these letters as a source. Almost by definition, they were written by people who admired Espartero and cannot be considered as representing the views of all Spaniards. Also, the letters came from people who were literate, although the orthography 
ongoing fame and popularity in the 1860s and 1870s and his role as Spain's first modern political celebrity (20).

\section{FAMILY TRADITIONS}

Oral tradition was a crucial vector for maintaining Espartero's fame. Perhaps the oldest form of oral culture in Spain is the romance, or folk ballad which emerged in the late $14^{\text {th }}$ century out of the earlier cantares de gesta and continued to be created into the $19^{\text {th }}$ century. Along with other forms of popular poetry, romances were also produced in cheap printed formats, part of the $l i$ terature de cordel, which was sold, hanging from a string, by street vendors (21). Contemporary events, and especially military conflict, were one of the romance's staple topics, and Espartero was the subject of at least one which was recorded in three different versions by folklore collectors working in the province of Leon in the second decade of the $20^{\text {th }}$ century. After a victory which cost many of his men's lives, Espartero is moved by the suffering of a wounded soldier, first to send him «un cirujano francés» and then, after the wounded man dies:
El Espartero echó carta al ospital
Que asta el mismo campo santo
Le bayan a acompañar
Con músicas y tambores
Hasta ayudarle a enterrar
Ahora digamos todos
Viba, viba nuestro General (22).

of many suggests that the writers' skills were limited. Some letter writers belonged to urban middle classes, or even elites, for example Santiago López Pelegrín who was a politician and, among other things, author of a book about bullfighting. Even so, the letters do begin to provide «the direct evidence needed to probe popular attitudes and motives» which John Breulliy has called for in the study of popular nationalism. «What does it mean to say that nationalism is "popular"?», in VAN GINDERACHTER and BEYEN (2011): 24. Espartero's papers remain in the possession of his descendants who generously gave me access to them.

(20) Lilti defines a celebrity as someone who was known by «un vaste ensemble de gens avec lesquels il n'a aucun contact direct, que ne l'ont jamais rencontré et ne le rencontrent jamais, mais que sont fréquenment confrontés a sa figure publique, c'est-a-sire, à l'ensemble des images et discours asociés à son nom». LILTI (2014): 13. The case of Espartero was slightly different: many ordinary people did have direct contact with him.

(21) BERESFORD (2005): 87-88; ÁlVAREZ B ARRIENTOS (2005): 324-325.

(22) «General Espartero», 014006-0001A; Archivo Fundación Ramón Menéndez Pidal, Madrid. 
Oral tradition within families played a particular role in sustaining the Espartero cult. In November 1868, Joaquín Mariano de Lobera described himself as 50 years old and having served under Espartero in the past; he was now «casado y con familia hoy me dedico a la educación de esta, también los inculco los principios liberales de que tanto ejemplo ha dado el pacificador de España». Santiago López Pelegrín wrote that his «buen padre», who had been a friend of Espartero's, «nos enseñó a pronunciar desde muy niños, [su nombre] como el nombre santo y respectable por ecselencia, como una especie de Providencia para nosotros sigue siendo hoy, y será siempre para mí y para todos los míos, el nombre augusto del héroe». A few months later, another admirer wrote that «Muy niño todavía mis padres me enseñaron a pronunciar el nombre de Espartero con el entusiasmo y veneración que se merecía el hombre que aseguró la libertad en nuestra querida España» (23). A José María López y López wrote from Sevilla in 1875 that, «niño aún» he had sent Espartero saint's day congratulations ten years before, «obteniendo una respuesta que conserve como uno de mis gratos recuerdos de la infancia». The passing years «no han borrado de mi corazón el afectuso respeto que heredé de mi padre hacia la persona de VE, en quien veo no solo al ilustre caudillo que supo poner término a la Guerra de los siete años, sino también al constante defensor de nuestras libertades» (24).

Republican politician and future President of the First Republic Emilio Castelar, who was born in 1832, had similar memories. In a speech to the Constituent Cortes in March 1869 recalled that «Yo me acuerdo siempre de cuando en las noches de Navidad estaba en el hogar al calor de la lumbera, acompañado de mis padres, y cuando la lluvia azotaba los cristales, me contaban aquella Guerra jigante y me decía: «Bendice, hijo mío, al general Espartero, porque ha vencido la Guerra y nos ha dado la paz». Nor could Castelar, who was also Professor of History at the University of Madrid, fully shake these childhood lessons. In that same speech he said that Espartero was one of only three generals in European history who had been able «to ally democracy with monarchy»; the other two were Lafayette and Garibaldi. (25)

(23) Joaquin Mariano de Lobera (Cádiz) to Espartero, 19 Nov. 1868, Espartero Archive (16-1868-77); Santiago López Pelegrín to Espartero, 11 Nov. 1868, Espartero Archive (16-186868); Pascual M. Estan... (Villena) to Espartero, 30 April, 1869, Espartero Archive (17-88).

(24) Espartero Archive (26) 479.

(25) CASTELAR (1877): 235,233. In an earlier speech, he described Espartero as «la paz en la sociedad; la libertad en la política; el representante de nuestras más gloriosas tradiciones históricas... y al mismo tiempo era tan sencillo en sus gustos, y en sus costumbres tan virtuoso que el pueblo, al mirarle, se veía a sí mismo; de suerte que este hombre extraordinario podia llamarse con razon la muchedumbre coronada». Ibíd., p. 146. Castelar was far from being alone among republicans in admiring Espartero. During the campaign to elect the Cortes Constituyentes that would write the new constitution, Fernando Garrido said that «aunque no defienda la forma republicana, es para nosotros republicano... y digno de ser el primer magistrado de la República Española». The «Cincinato español» was too great a figure to put on a throne, «solo la gran misión de un Washington es digno en nosotros de ofrecerle y en él aceptar». El Cronista, December 31, 1868. 
Another form of transmission of the Espartero cult through families was naming. At the start of his biography of Juan Prim, Pere Anguera claims that his subject's fame was greater and longer lasting than Espartero's, as the latter only «se refleja en una inusitada abundnacia de Baldomeros» (26). Deriving from Germanic words for brave and famous and entering Catholic naming practice after a $7^{\text {th }}$ century martyr in Lyon, Baldomero was far from a common name in Spain (27). While we lack overall statistics on how often the name appeared and whether it became more commonly used after the time Espartero became famous, there is evidence in the letters he received of people naming their children after him. One Baldomero Martínez, from Mahón, wrote in January 1868 that his deceased father had been «fiel y adicto a la causa de VE». This Baldomero was an opera singer and he was going to dedicate his upcoming debut concert, as was tradition, to «la persona que más aprecio y respeto... En atención a estar dedicada la function, al Excmo. Sr. Duque de la Victoria, el teatro estará iluminado y puesto su retrato el en lugar preferente». (He included a poster for the event as well as a photograph of himself.) (28). Benito Ferrer wrote from Sevilla that he had been planning to visit Espartero in Logroño, a considerable journey at the time, but had been unable to because his son, Baldomero, was ill (29).

\section{IMAGES}

Images were an important support for Espartero's ongoing fame. Nicolás Estévanez (1838-1914), the son of a military officer whose political sympathies were between Progressive liberalism and republicanism, recalled that his father's study had «no había más adornos que los retratos de Voltaire, Quintana, Zurbano, Espartero, Mazzini and Garibaldi». (30) But possession of an image of Espartero was particularly true for the lower classes. Publisher Benito Hortelano described his decision to publish a «cheap» biography of Espartero in 1848 as a commercial operation motivated by his observation of his ongoing popularity among the lower classes of Madrid: «Algunos retratos malos y raquíticos que se había estampado cuando era Regente, el pueblo los buscaba como reliquias y los colocaba en la cabecera de la cama y algunos hasta los ponían luces, como si

(26) ANGUERA (2003): 7. By contrast, Anguera says, decades after Prim's death, Oscar Wilde would casually mention him in The Picture of Dorian Gray. This is a very different kind of fame from the one being discussed here.

(27) This may help explain why Espartero chose to be known as Baldomero, which was actually his middle name. San Baldomero's day in the santoral is February 27, which was Espartero's birthday. According the the Instituto Nacional de Estadística's padrón de nombres continuo, as of January 2012, Baldomero ranked 406 on the list of men's names in Spain.

(28) Baldomero Martinez to Espartero, 23 Jan. 1869, Espartero Archive (17-45).

(29) Benito Ferrer to Espartero, 5 June 1869, Espartero Archive (17-95).

(30) EsTEVÁNEZ (1903): 14. 
fuese la efigie de un santo». Part of Hortelano's marketing strategy, which was aimed squarely at «artesanos», was to offer subscribers a «retrato de cuerpo entero» (31). In February 1854, Otway, the British ambassador to Madrid assessed Espartero's popularity after eleven years away from active politics: «There is no doubt that the lower orders of Madrid, Saragossa and in most of the principal towns are Esparteristas... Like Napoleon in France, his portrait is universal in the huts of the poor, and his alone». Five months later, in the midst of the revolution, the ambassador had recourse to religious imagery: «The Duke of Victory's portrait is displayed in all the principal streets surrounded with flowers and lamps, as would be that of a Madonna» (32). (Keeping with the religious motif, an engraving of the time portrayed a militiaman celebrating Saint Baldomero's Day. Another proclaimed simply him the «personificación de la Libertad».) Seven years later, in July 1861, the town of Iznajar (Córdoba) was the scene of a republican revolt, known locally as the «War of Bread and Cheese». One of the leaders, Joaquín Narváez, a distant relative of the Moderado politician Ramón María Narváez, was executed and the as part of the protest by the people of the town, «the portrait of Espartero...competed with the saints for occupying the pre-eminent place of devotion in their homes» (33).

A number of the letters Espartero received after the Revolution of 1868 mentioned ownership of his image and the importance it held. José María Sánchez, who had fought under Espartero during the Carlist War and then served in his honour guard during the Regency, wrote that all his friends were Esparteristas and «con aquellos que es su ídolo el retrato de VE y a imitación mía, le tienen erigido un altar que ocupa en sus casas el lugar más preferente». A man from Villena, who had had learned about Espartero from his parents, had never lost his admiration for him and still hoped - «todo mi afán» - to meet him in person, requested a photograph or autograph, «para conservarlas como prendas de inestimable valor, cual un rico tesoro, guardándolas en la familia como la joya más preciada» (34). Finally, Juan Angel said that he had celebrated Espartero's saint's day every year since 1836 - «siempre a cido para mí el día más dichoso del año» - and that the letter Espartero had sent in reply to him four years earlier «la alaga de más valor que tengo en mi casa, mientras viviré yo, y mis hijos, que todos profesan mis hideas, esta carta... la tengo colocada entre el

(31) Hortelano (1936): 96-98 His strategy included dedicating it to the former National Militia and listing the author as an ex-militiaman, and distributing the instalments on Saturday afternoon, when the «artesanos» got paid and had money to spend. The project was a success: in a few days he had 8,000 subscribers and he realized 140,000 pesetas in sales in 18 months.

(32) Cited in Kiernan (1966): 47, fn 2; Otway to Clarendon, 22 July, 31 August, 1854, Foreign Office 72, 844, PRO.

(33) Cited in THOMPSON (2009): 159-160.

(34) José M. ${ }^{a}$ Sánchez to Espartero, nd., Espartero Archive (17-60b); Pascual M. Estan... (Villena) to Espartero, 30 April, 1869, Espartero Archive (17-88). 
cristal y la estampa del retrato de Buestro ES, y cuando hago iluminación cuantas preguntas se me asen sobre dicha carta, I que orgulloso me pongo yo» (35).

A letter Espartero received congratulating him on being named Prince of Vergara in 1872 combines family tradition with the importance of images. The correspondent, Francisco Javier Ygualada, recalled that in 1840 he had hosted Espartero at his home in Alcira. Now, thirty-two years later, he had:

[...] un pie en los primeros peldaños de mi sepulcro, y antes de penetrar en la eternal mansión quisiera poseer alguno de vuestros conceptos, así como vuestra fotografía, en cambio de la que tengo el gusto de remitiros.... Si tan alta honra merezco, y si como es natural sobevivo poco tiempo, no temáis por el uso que pueda hacerse de vuestra venerable efigie, porque solo liberales ecsisten en mi dilatada familia, y estad seguro de que será disputada por mis herederos como la mas preciada joya que pueda legarles y pasará a las sucesivas generaciones con el sacrosancto respeto que inspiran siempre los eminentes heroes de la patria (36).

Many of these letters illuminate a point made by Simon Morgan: «Although many commemorative objects began life as mass-produced commodities, we should remember that they did not retain this status... through display about the person or in the home such objects attained a status of singularity and would potentially have played a part in constituting the self-identity of their owners, insofar as they identified themselves with the principles of the figures they represented. Objects and images told stories not only about the figures they depicted but also those who owned, displayed, or used them» (37). Showing Espartero's image or autograph to friends and family and passing it on to the next generation were as important as the simple act of ownership.

The last letter also points to the particular importance of items that had been touched by the great man, something which comes through elsewhere. Gregorio Fernández de Barroete, who had been a volunteer during the Carlist War, was moved by news of the visit Espartero received from Alfonso XII to adding that a reply from Espartero «añadiría una timbre más de Gloria... legado a mis hijos como recuerdo imperecedero de este veterano» (38). A group of admirers from San Andrés del Palomar included a particularly emotional anecdote in a letter to Espartero to congratulate him on his birthday. As they were writing, a friend who lived nearby dropped in and said:

Ya beis, hase mas de 20 que estoy pribado de andar y me encuentro imposibilitado, además tengo doble edad mas que bosotros, bostros bendrá un día que hiréis en Logroño a bisitar a Espartero, yo no lo podré ber pero a lo menos quisiera que nos

(35) Juan Angel to Espartero, 11 Jan. 1869, Espartero Archive (17-23).

(36) Espartero Archive, (26) 278.

(37) MORGAN (2011).

(38) Espartero Archive, (20) 1875-23. Espartero received at least one letter from abroad requestiong his autograph. From Frankfurt but written in French, it came in September 1878, at the very end of Espartero's life. Espartero Archive, (20) 1878-11. 
embiase su propia firma y cada vez que la bería se me alegraría el corzaon, y dicho esto empezo a llorar, a sus lágrimas siguieron también las de todos los amigos. ¡O momento dichoso! Aquellas lágrimas afianzaba la lealtad de aquellos corazones (39).

Similarly, Angel Bellogín commented that while most of the veterans who had broken down in tears when Espartero visited Valladolid in 1856 to inaugurate the railroad were dead by September 1868, «sus hijos conservaban cual preciosa reliquia la licencia de sus padres» (40).

What type of images are we talking about here? The European craze for collecting cartes de visite and pasting them in albums, which took off after Disderi's invention of these small photographic portraits in 1854, did not pass Spain by. There was a «verdadera industria» producing the things and a particular kind of window shopping took hold in Madrid and Barcelona. In 1861 Ramón Mesonero Romanos claimed that people would spend hours watching the construction in Madrid's Puerta del Sol or «en recorrer uno por uno los mil retratos-tarjeta expuestas a las puertas de los fotógrafos» (41). By 1856, Madrid was experiencing what Antonio Flores called «retrato-manía»:

De ese cambio recíproco [de retratos] prescinden pocas personas. Y el que no tiene amigos, como no puede prescindir del album de retratos, compra los que quiere, los que puede, porque ya nos venden a todos en pública almoneda. Solo así es possible tener el retrato de todos los reyes, de todos los sabios, de todos los artistas y de todos los fenómenos del universe. Nadie se escapa ya de ser retratado y de ser vendido (42).

Espartero was neither a king nor a wise man nor an artist but his portrait was one of the many that found their way onto a carte de visite, although the few that remain appear to have been taken after 1860, when he was twenty years older, and stouter, than the Romantic icon in Antonio María Esquivel's widely reproduced portrait. These images undoubtedly helped sustain Espartero's fame, but there were other, less technologically advanced types of image that were undoubtedly even more influential.

Espartero was the subject of the aleluya, another long-established genre, although one which was commercialized in the 1840s. The aleluya originated in Cataluña, where it was known as an $a u c a$, in the $17^{\text {th }}$ or $18^{\text {th }}$ century. It became nationally known in the 1840s, after Joan María Marés moved from Barcelona to Madrid and began to produce what would be the most important series, consisting of 125. Aleluyas continued to be produced until the 1930s, but they were particularly important between 1850 and 1900. In its commercial form, the aleluya measured 30 by 42 centimetres, was printed on cheap paper, and consisted of eight rows of six crudely-drawn images, each accompanied by a

(39) Espartero Archive, (23) 164.

(40) BELloGín (1993): 329.

(41) LÓPEZ MONDEJAR (2005): 51-56.

(42) Cited in ibid., p. 52. 
small amount of rhyming text in a metre easily committed to memory. (In a country with very high illiteracy rates, keeping text to a minimum was important.) The subject matter was varied, including literary works, such foreign ones as Robinson Crusoe, The Count of Monte Cristo and The Wandering Jew, among them, although recent history and biography predominated. With «un fuerte aspecto didáctico» and sold by «los mismos ciegos y botoneros de la literatura popular en las corridas y ferias colgados de un palo... en pequeñas librerías o en los puestos de las plazas», the aleluyas were clearly intended for a lower-class public, precisely the kind of people who were reported to have Espartero «altars» in their homes (43). They were also cheaper than the cartes de visite and were diffused more widely (44). In addition, they appealed to children, who would often cut out the images and use them as an early kind of cromo for collecting and trading, and might even have been used in schools to compensate for the scarcity of books (45).

The Historia del General Espartero was number 58 in the Marés series, but there was at least one other, produced by a Barcelona publisher (46). Marés, in fact, produced at least two, one of them serving almost as a news flash about Espartero's resignation from government in 1856. After an introduction: «Insigne será en la Historia/el Duque de la Victoria», the aleluya told the story of Espartero's life: there was one square devoted to his service against Napoleon and four to his years in America. With twenty-three, the Carlist War gets the most attention, including Luchana: «Muestra en Bilbao su valor/derrotando al sitiador», and Vergara: «En paz, en abrazo estrecho/el convenio queda hecho». His involvement in politics to the end of his Regency receives thirteen, including the bombarding of Barcelona in 1842: «Marcha el Duque a Barcelona/que otra vez se insurreciona». His exile in England: «Es en Londres recibido/como varón distinguido», return to Spain in 1848 and retirement in Logroño: «Vuelve a España de paisano/y vive como aldeano», receive four images and the revolution of 1854 two: «Vuelve con pecho sincero/a gobernar Espartero» and:

(43) On aleluyas see BIRNER (1995) and Jean-Francois Botrel, «La serie de aleluyas Marés, Minuesa, Hernando», http://www.cervantesvirtual.com/obra-visor/la-serie-de-aleluyas-marsminuesa-hernando-0/html/0133c1ee-82b2-11df-acc7-002185ce6064_7.html, «ÁLVAREZ BARRIENTOS (1977): 24-6. On the politicizing potential of another type of visual product aimed at ordinary Spaniards during the War of Independence, see MARTín (2007). For the importance of broadsheet ballads in spreading news to an illiterate public in Italy see FINALDI (2011).

(44) An inexpensive carte de visite might cost 2 reales while 500 aleluyas could be purchased for 32 reales, a fraction of the price. LóPEZ MONDEJAR (2005): 52; Botrel, «La serie de aleluyas», fn 16 . Aleluyas were produced in editions of 5,000 and many went through multiple editions.

(45) Cerrillo Torremocha and Martínez González (2012): 39-44; Antonio, Martín, «Las Aleluyas, primera lectura y primeras imágenes para niños en los siglos XVIII-XIX. Un antecedente de la literatura y la prensa infantil en España», http://pendientedemigracion.ucm.es/ info/especulo/numero47/aleluya.html

(46) Both can be found on the website of the Fundación José Díaz; http://www.funjdiaz. net/aleluyas1.php?t=Espartero 
«Luego en nueva reacción/presenta su dimisión». The aleluya leaves the overall impression of a valiant and victorious soldier, a simple man who does not lust for power and sides with the people (47). Alfredo Opisso, who was born in Tarragona in 1847, described the impact of the Espartero aleluya:

[...] en mi niñez... una de las aleluyas más populares era sin duda la de Espartero. Uno de los grabaditos lo representaba en un taller de carpentería y decían muy oportunamente los versos:

Desde niño placentero

Ya comienza a ser guerrero.

Y nadie diría la suggestion este pareado ejercía en las imaginaciones infantiles, despertando en ellas las más vehementes emulaciones esparteristas (48).

Another form of cheap publication which became important in the middle of the $19^{\text {th }}$ century also helped keep Espartero's name alive. This was the series of contemporary histories and biographies dealing with the period between the Napoleonic invasion and the Moroccan War of the early $20^{\text {th }}$ century which formed part of the Spanish «bibliothèque bleu» (49). Between 16 and 40 pages in length, these books were often adapted from longer volumes intended for elite audiences. With numerous editions published in Barcelona, Madrid, Palma and Reus, Espartero was the most popular individual subject in what Botrel describes as a second rate subaltern history. As the prologue to the 1851 edition of the Historia del General Baldomero Espartero explained, it was written «con mesura, con comedimiento, sin pretensiones, y de una manera sencilla» for «lo que se llama el verdadero pueblo, para esos que no tienen grandes medios para hacerse de libros más voluminosos», and was intended «a ilustrar al pueblo español dándole a leer las vidas y hechos de los hombres que más se han distinguido en nuestra época para que con la lectura de estos hechos aprenda y estudie la fisonomía de los tiempos azarosos que corremos» (50). The purpose was to narrate:

[...] los sucesos que marcaron la carrera de este célebre caudillo que tantos días de gloria diera a su Patria en los momentos que la ignorancia y la superstición la atacaban con feroz empea para privar de su naciente libertad.

El general Espartero habrá cometido faltas, porque ningún hombre es tan impeccable que deje de cometerlas durante un trancurso de una carrera sembrada de escollas y peligros como es la de la política,; pero de todos modos el general Espartero tiene un corazón grande y magnánimo, y sus deseos, estamos ciertos, han sido los de hacer la felicidad de su país, y tal vez lo hubiera conseguido sino hubiese

(47) The aleluya produced in Barcelona starts slightly differently, «De la España Gloria/ Duque de la Victoria», and ends before the Revolution of 1854.

(48) OpISSO (1908): 3.

(49) The following is based on Botrel $(1986,1999)$ According to Botrel, the book was published in Madrid in 1847, 1847, 1858, 1866, 1874 and 1879.

(50) Historia del General Baldomero Espartero, Duque de la Victoria y de Morella (Madrid, nd). As the story ends with Espartero living in Logroño after his return to Spain in 1848, it is probably the 1851 edition. 
rodeado de malos consejeros, y no hubiese un partido poderoso valídose de los medios más estraordinarios para derrocarle.

The subject was «los hechos consumados de nuestra revolución» in which Espartero had played such an important role, «sin comentarios de ninguna especie, tanto porque no nos tache de parciales, como porque en ninguna manera queremos incurrir en censura» (51).

In contrast to this large number of cheap, popular biographies almost no full-length biographies intended for a more sophisticated and affluent readership were published in these years. There had been a flurry of books during and immediately after Espartero's Regency, but Hortelano's 1848 effort mentioned above would be the last one for many years. (52) Indeed, it would appear that between 1848 and 1868, when Espartero once again became a public figure, only one such biography appeared, Pedro María Hidalgo's obscure 420-page Espartero: su historia y la de la guerra entre Don Carlos María Isidro de Borbón y su sobrina Doña Isabel II, which was published in Leon in 1866. The book is an ardent defence of Espartero, claiming that even previous positive biographies had not fully recognized his accomplishments, «atribuyéndolos a la Fortuna, como si esta Diosa del paganismo estuviera enamorada de este mortal Soldado». Such an explanation could not satisfy «a una inteligencia elevada, a una razón sólida y nutrida, a un espíritu varonil», and in five chapters of highly unequal length: student (4 pages), soldier (312 pages), Regent (62 pages), «elevado» (6 pages) and «caído» (13 pages), Hidalgo argued that Espartero's success came not from luck but from his own qualities. Written in complex language, the book was completely without illustrations (53).

\section{WRITING TO ESPARTERO}

As already mentioned, with the exception of the revolutionary bienio of 1854 to 1856 , Espartero spent virtually his entire life after returning from his British exile in 1848, more than thirty years, living Logroño where his wife had her lands. This quiet life as a «hacendado riojano» was what Espartero honestly wanted: in many of the letters he wrote to his wife Jacinta during the Carlist War he expressed his wish «bolber a ver mi casa de la que no quisiera separarme

(51) Ibíd.

(52) For a brief discussion of some of these, see SoubEYroux (2000).

(53) Hidalgo (1866). The website of the Fundación Sancho el Sabio has a digital version of the book: http://www.memoriadigitalvasca.es/handle/10357/1102. A lawyer, Hidalgo had served as a juez de primera instancia and Presidente del Consejo provincial de León. He was also author of Práctica criminal: Procedimiento en las causas de contrabando y defraudación (León, 1847). Hidalgo served as a deputy in the Asamblea Nacional in 1873 and later wrote a pamphlet, Vindicación de la asamblea republicana disuelta por la fuerza del ejército a las órdenes del señor Pavía, Capitán General de Madrid en la madrugada del 3 de enero de 1874 (León, 1874). 
pues no deseo más que vivir en ella sin más mando de ninguna clase» (54). Even so, it may well have acted as «inspired separateness», a technique of «enhancing their stature by making themselves scarce» used by some European «celebrities and charismatic leaders» (55). Ildefonso Antonio Bermejo, who had written a novelized life of Espartero in 1847, pointed to this in his history of the revolutionary years 1868 to 1874 :

¿Y á qué ha debido esto el duque de la Victoria? A su voluntario ostracismo, á su perserverancia en vivir alejado de los afanes de la política. Escoja una fórmula para salir de apuros en lances apretados, así como Espartero tiene escogida la suya, y con la cual le ha ido muy bien. Con un cúmplase la voluntad nacional ha tenido el conde de Luchana baluarte fuerte y bien artillado contra todos los que han querido sacarle de su retraimiento. Cuanto mayor ha sido su aislamiento, más ha crecido su popularidad; cuanto ménos ha permitido que se use de su nombre, más se ha levantado su importancia; cuanto mayor ha sido su modestia, más ha aumentado su fama, y cuanto menor ha sido su ambición, más se la ha buscado. Si el general Espartero, en su estado valetudinario, se hubiera convertido en jefe militante de bandería, capitán de alguna facción batalladora, elemento de pelea, arma de reyertas entre intrigantes de piso bajo; si hubiera consentido en que su nombre hubiera sido bandera de perturbaciones, seguramente habría tenido la suerte desdichada que le cupo al duque de Montpensier; pero como hizo todo lo contrario, llegó el caso hasta de que la nación consultara su voluntad en la vacante del Trono (56).

Whether this staying above the fray was a conscious strategy or not, Espartero's separation from public life did not make him inaccessible to his supporters nor remove him from their memory. As the letters discussed so far make clear, they did not hesitate to write to him. This was not simply a function of the extraordinary circumstances created by the Revolution of 1868; they had been writing him for years and continued to do so almost up to his death, a correspondence which created the «intimacy at a distance» described by John Thompson and which, to paraphrase Edward Berenson, «reveal[s] the importance [Espartero] had assumed in the mental worlds of a great many [Spanish] men and women» (57).

The largest number of letters - and later telegrams as well - came around February 27, Espartero's birthday and Saint Baldomero day. In 1864, José Fayas, from Barcelona, wrote on behalf of himself and his son, Baldomero, while Ma-

(54) Espartero de Jacinta, 8 July, 1837, Espartero Archive.

(55) BERENSON and GIOLI (2010): 12.

(56) BERMEJO (1875): 178-179. Adrian Lyttleton comments that Garibaldi's long residence on Caprera «secured for him the identification with Cincinnatus, already achieved by George Washington, with whom Garibaldi was also indirectly compared. [He] preserved the more archaic and rural virtues of the Cincinnatus myth in his retirement at Caprera». LYTTLETON (2012): 43. Exactly the same could be said about Espartero, with the difference that he was frequently directly compared to Washington, especially by Spanish Republicans.

(57) THOMPSON (1995): 219-20; BERENSON and Gioli (2010): 39. The original quote refers to the French colonial hero Hubert Lyautey. 
riano Gil y Alcayde, from Barcelona, proclaimed that «Querer a VVEE es más que el premio gordo de la loteria...(que viva 1000000000000 años, y lo mismo la Duquesa)». Ramón Miret, also from Barcelona, wrote that he had decided to celebrate Espartero's birthday in 1866 «esponiendo e iluminando el retrato de VE al que dará una serenata la música de uno de los cuerpos de milicia ciudadana». He also asked Espartero to accept «el retrato de este su apasionado» (58). In 1871 Espartero even got a birthday telegram from a group of «presos políticos» (59). Some people, like F. González de la Vega, wrote every year: «siempre con motivos de sus días le Saluda y jamás perderé esta costumbre» (60).

Espartero's birthday could even be connected to current events. In 1873, with Spain living under the First Republic, which had been proclaimed only sixteen days before his $80^{\text {th }}$ birthday, a group from Málaga wrote that without Espartero's exploits, «tal vez hoy no brillaría en España el sol divino de la República» (61). That Espartero had always been and remained a firm monarchist was, it seemed, irrelevant (62). Five young «ardientes partidarios de la libertad y la democracia» recalled Luchana and Vergara which had saved Spain «del cruel absolutismo que aun destruye nuestras moradas y asesina a nuestros hermanos con verguenza de la civilización, de la razón y del derecho» (63). In 1876, a number of residents from Pedro Muñoz, in Espartero's native Ciudad Real, wrote that they had received news of «la derrota y entrega de varios batallones Carlistas» and had «visto con gusto que coincide tan agradable noticia con el cumple años de S.A.». Santiago García Santa Olalla, who described himself as an 84 year old priest who had spent 21 years as a canon of Seville cathedral, wrote that «ahora mayor que antes» the celebration of Saint Baldomero day «debe sostenerse... que bien puede caracterizarse de Nacional. Hoi vuelve a respirar la Patria cuando empieza a disiparse, a paso largo, el mal de una guerra fratricida». Spain he said, should thank God that «nos haya deparado ahora caudillos entendidos y valerosos, que imitando a VA pongan fin a tan injustificable rebelión» (64). Some letters made reference to Alfonso XII's visit to Logroño in February 1875. For example, the Sociedad de Milicianos Veteranos del año 1823 of Barcelona thanked him for being «el campeón constante de nuestras livertades patrias» and noted that Alfonso XII, «nuestro joven y legítimo monarca» had done the same in visiting him and giving him «un fraternal abrazo» (65).

(58) Espartero Archive, (23) 187, (23) 331, (25) 1866-422.

(59) Espartero Archive, (21) 1871A-20.

(60) Espartero Archive (25) 1866-427

(61) Espartero Archive, (26) 358.

(62) Espartero's was a name which had had become detached from any specific program or position to «float free from its political moorings» as Lucy Riall has written about the cult of Garibaldi, and could be appropriated for a variety of political causes. RIALL (2007): 390.

(63) Espartero Archive, (26) 363.

(64) Espartero Archive, (26) 519, 515.

(65) Espartero Archive, (26) 470. 
Some correspondents sent poems in Espartero's honour. Miguel Planas and his friends composed the following «a pesar de la triste calamidad que estamos atravesando por la carestía de trabajos.»
A ti soldado baliente
Del progreso adicto amigo
Benimos umildemente
A decirte con cariño
Lo que nuestro pecho siente.
Del dia de tu patron
Olbidarnos no podemos
Mira, haun que entre afliccion
Estamos, hoy te ofrecemos
Ruda felicitasion.
Oras de jubilo y gloria
En ella te deseamos
Separa hoy de tu memoria...
Por lo mucho que te amamos
A los que envidian tu historia
Regojiste este dia
---- que a tu luz nada empaña
Es justo que la alegría
Reine en ti, pues toda España
Oy siente gran melodia (66)

Antonio Martínez also sent a poem in 1864 to show that «ni el tiempo ni mis desgracias de familia pueden mitigar el afecto entusiasta que siempre os he profesado y profesaré». In his reply, Espartero write that «[h]a gustado tanto su composición poética, que muchos amigos han sacado copia» (67).

Others described celebrations organized for the occasion. These could be modest activities involving an individual and a group of family members or friends. For example, in 1864, twenty-three men from Cambrils (Tarragona) «reunidos como todos los años para celebrar con un banquete vuestro santo patrón bajo vuestro retrato y el de SM cuyo trono tan dignamente supiste defender, asegurando la libertad de nuestra patria», wrote to wish Espartero long life. Another group, in Figueras, had «un espléndido y entusiasmado banquete en celebridad de tan fausto día» during which the toasts were especially lively «tanto por su patriotismo como de poder librar el vino» from Espartero's own production, «honor que a pocos cabe» (68).

(66) Espartero Archive, (23) 164. For other poems see (23) 268, 289.

(67) Espartero Archive, (23) 113.

(68) Espartero Archive, (23) 1854-1864-268. 
These celebrations could also be more elaborate affairs that engaged much of the population of a town or village, as in Utiel in 1870. It began at eight the previous evening when «se iluminó el pueblo espontáneamente» and the playing of the «retrete» brought «un inmenso gentío» into the square. Then:

[...] vuestro retrato apareció a las puertas de la casa consistorial en medio de un respectable guardia de honor compuesta de las clases del batallón de voluntaries que lleva vuestro nombre. Un ¡Viva Espartero! Salió de aquella multitude que se repitió mil y mil veces. La banda del batallón tocó vuestro himno... y en medio de las más ardorosas aclamaciones fue ostentándose vuestro retrato por las principales calles de la población.

The band played in the square until midnight to crowds who gathered around bonfires. At 9 the next morning, Espartero's portrait, guarded by members of the volunteers, was displayed on the balcony of the town hall. This was followed by mass and then a communal lunch, after which an «ejército... de pobres mendigantes, en su mayor parte forasteros», were fed. When they had finished eating, the poor «intuitiva y espontáneamente» started a dance. When evening fell, the «retrete» was sounded again and Espartero's portrait was withdrawn from its place of honour (69). The following year, the mayor of Valls (Tarragona), sent Espartero a congratulatory telegram to let him know that the «Ayuntamiento, guarnición y pueblo» had celebrated his saint's day and that «se ha plantado con el mayor festejo el Arbol de la Libertad que V.E. tan heroicamente ha defendido con la espada y consolidado con sus virtudes» (70).

Espartero's mailbox would also fill as December 24 approached, as many wrote to recall the great victory of Luchana. In 1871 «el Bilbaino» Arturo de Marcuartu «felicita con todo corazón ... al Vencedor de Luchana, al pacificador de Vergara» while from Alba de Tormes (Salamanca), «Carabineros y Guardia Civil» congratulated «el Pacificador de España por la memorable batalla de Luchana» (71). In 1874, Eusebio Perera wrote, «Como en otras ocasiones» to remember Luchana, «su más legítimo triumfo», and to let Espartero know that he had written an article for La Iberia «con el patriótico fin de rendir justo y merecido tributo de gratitude y admiración a todos los héroes que en ella tomaron parte» (72). Thirty-seven years after the battle, Emilio Castelar, then President of the Republic, would send a congratulatory letter (73).

(69) Espartero Archive, (25), 1855-392.

(70) Espartero Archive, (21), 1871-A5.

(71) Espartero Archive, (21), 1871B-33.

(72) Espartero Archive, (20) 1874-33.

(73) CASTELAR (1908): 381-82. There was also at least one ongoing institutional remembrance of Luchana: an annual ceremony organized by the municipal government of Bilbao. 
Luchana could also serve for other purposes, such as the publishing project proposed to him in 1875: «Espartero en Luchana y Cervantes en Lepanto, son dos glorias que se enlazan, no solo por el brillante de los hechos sino por ser estos llevados a cabo por dos españoles valientes, honrados y virtuosos». What is most interesting is the implication that Espartero was the better known of the two; while he was already one of Spain's «preclaros hijos», wouldn't remembering the name of Cervantes also «ha de asomar el entusiasmo»? (74)

His birthday and the anniversaries of Vergara and Luchana were all annual events, but Espartero's admirers also wrote on specific occasions, such as when Amadeo I bestowed on him the title Prince of Vergara in January 1872. For Cosme Ceperuelo, even this title was insufficient recognition of what all Spain owed to the «pacificador del mundo». (He also requested a reply, «puesto que la firma de VA es para mí una herencia»). Francisco de A. Planas Casals expressed his wish that the Progressives would once again rally around Espartero, «Unido y compacto es digno de su nombre, del contrario va por el lado hecho trizas», and concluded by asking whether Espartero had received his letter of December 24 congratulating him on the $35^{\text {th }}$ anniversary of the «memorable noche de Luchana». Miguel Subiran Capucha, who signed himself «El Beterano del año 1823», wrote in lieu of his making the pilgrimage to Logroño; his «abanzada edad de 76 años cumplidos y enfermo... no me permiten ponerme en camino como lo an hecho mis compañeros beteranos de Zaragoza y Madrid» (75).

Some of these letters favourably contrasted Amadeo's action with the way Espartero had been treated before. A correspondent from Madrid wrote: $\ll_{i} \mathrm{~A}$ cuantas reflexiones no se presta esta distinción hecha por un Rey que hace un año ha venido de tierra extranjera! Lo cierto es que ha venido a recompensar con muestras de sumo aprecio al héroe de nuestras discordias civiles que acaecieron hace más de 32 años.» Francisco Javier Ygualada, from Valencia, lamented that it was a foreign prince who had recognized Espartero's contributions while «ingratas situaciones puramente españolas no haya hecho justicia a vuestros nuna bastante ponderados merecimientos» (76). The 80-year-old, retired general clearly had a lot to offer this novice monarch of still-uncertain legitimacy.

(74) Espartero Archive, (20) 1875-027.

(75) Espartero Archive, (26) 244, 266, 282.

(76) Espartero Archive, (26) 273, 278. 


\section{CONCLUSION}

This discussion arose out of the specific question of how Espartero managed to remain so famous for so long after his public life had ended and to locate it in the merging historiography of celebrity. It has used a variety of sources, images, aleluyas, romances, cheap publications and, above all, letters Espartero received from across the country, to argue that this phenomenon was largely, albeit not exclusively, driven from below and to locate it in the emerging historical discussion of celebrity.

This study also connects to a number of larger issues in European history in general and the history of Spain in particular. The study of heroes such as Espartero has become an important concern for historians of nationalism and of the newly-emerging liberal public sphere, although less in Spain than elsewhere (77). The persistence of the cult can help address Maarten Van Ginderachter and Marnix Beyen's question about what the nation «mean[t] to ordinary people». It also illustrates the autonomous activity which could «construe a national identity out of elements that are not always scooped out to them by the elite» that they suggest was an important part of European nationalism: «did ordinary people reject the national canon as it was presented to them and fashion their own national heroes and narratives?» (78). Espartero was precisely such a hero, sustained from below long after most of the liberal elite had written him off as politically irrelevant (79). Indeed, for many Spaniards, and for a long time, Espartero would be the embodiment of the liberal - and even the democratic - nation (80).

The persistence of the Espartero cult also provides insight into the particular role of military men in liberal nation building, marking the full fruition of what Robert Hocquellet and Stéphanne Michonneau describe as the «processus... long et heurté» which started with the War of Independence and

(77) Riall (2007); Gewarth (2005); BerEnson and Gioli (2010); BerENSON (2012). See also the July 2009 special issue of European History Quarterly on hero cults and the nation which includes an article by John Tone on Agustina de Aragón. On Spain see Romeo Mateo (2003); CASTELls et al. (2009) and ShUbert (2012). Curiously, much of this work on Spain has been about heroines.

(78) VAN GiNDERACHTER and BEYEN (2011): 8, 11.

(79) An outstanding example of the disjunction between the vision from above that from below is Angel Fernández de los Ríos' Historia de las luchas politicas en la España del Siglo XIX which was commissioned by the Progresista party and which appeared in 1864. Fernández de los Ríos's portrait of Espartero could not be more negative: he was «el hombre de la pereza y la vacilación» and his «deplorable triunfo» in 1840 was «la rémora más grande para nuestra reforma política». Vol. 2, pp. 418-419. On the Progresista construction of a corps of heroes, in which Espartero did not find a place after 1856, see ZuRITA ALDEGUER (2014).

(80) Zurita Aldeguer concludes by remarking that «[r]esulta complicado saber cómo la gente común del mundo progresista tradujo todas esas ideas principales». The Espartero cult is at least part of the answer. 
matured during the Trienio Liberal, a process which radically changed the image of military officers and allowed them to become liberal heroes, «d'incarner una certaine idée de la nation libérale» (81). The political role of military men connects to questions of gender roles, and especially concepts of masculinity, in in the new liberal society of $19^{\text {th }}$-century Spain. María Sierra has reminded us of the importance of honour for men in politics and that «[s] er valiente constituiría una de las garantías» of achieving it, while in her discussion of democratic masculinity Florencia Peyroux has explored Democrats' understanding of the democratic man. He was «el ciudadano, que se definía idealmente como un individuo autónomo, dueño de su razón, de su voluntad y de su destino, libre y digno, buen trabajador, participativo y vigilante, implicado en la vida pública y dispuesto en todo momento a tomar las armas por la patria y por la libertad» as well as someone who displayed «una conducta ejemplar», with austerity as a particular virtue, in both his public and private life. If, as she claims, this ideal of the male as head of the family also applied to the government, then who better to preside over the national family than Espartero, especially as he got older and could be seen as a true patriarch? That he and his wife Jacinta were childless meant that Spaniards would be their only children (82). To what extent did his power of attraction derive from the way in which he embodied the virtues of the liberal - and even democratic - male family? These were precisely the qualities emphasized in the petitions calling on the Cortes Constituyentes to proclaim Espartero king. He was, they proclaimed, «el Pacificador de España», «el Héroe de Luchana», «el Patriarca de nuestras libertades», the «personificación de la Soberanía Nacional», «Cincinato de nuestra edad moderna» and the «Genuina representación de la idea del siglo». He was also a model of virtue, something which had immense weight in the aftermath of the scandalous behavior of Isabel II and her court. He was also «el modesto retirado de Logroño», «el Gran Coloso de virtud, abnegación y patriotismo» and the embodiment of «las virtudes del liberalismo, desinterés y moralidad probadas» (83). These same tropes: his success as a general and his role as the «pacificador»; his unflagging championing of liberty; and his personal qualities, particularly his honesty, modesty and lack of ambition, echo through the letters Espartero received after the revolutionary uprising of September 1868 (84).

Such a focus on gender can also help explain one of the issues that has long bedeviled $19^{\text {th }}$-century Spanish - and Latin American - history: the figure of the caudillo. In an important article, Jaime E. Rodríguez O has suggested that the

(81) Hocquellet and MichonNeau (2008): 105.

(82) Sierra (2012): 221-222; PeYrou (2011): 168-169 and GómeZ Urdaña (2005), which is based, ironically, on the personal correspondence of Espartero's great political rival, Salustiano Olózaga. The key work on masculinity is CoNNELL (2005).

(83) Legajo 229, Archivo del Congreso de los Diputados, Madrid.

(84) There are hundreds of these letters in Espartero's private papers. 
political importance of military men such as Riego, Itúrbide and Santa Anna and I would add US presidents Andrew Jackson, Ulysses S. Grant and a number of other $19^{\text {th }}$-century presidents, as well as Espartero - derived from their being some of the best known and widely celebrated people in their societies, «figuras carismáticas que captaban la imaginación popular» (85). Rodríguez O does not discuss ideas of masculinity but these surely also played a role in the making of the caudillos. As successful military men at a time when «many aspects of modern masculinity were forged in the nexus of politics and war» and «the interrelated nature of politics and war in modern history cannot be properly understood if we do not take into account masculinity's part in maintaining their relation» (86) it is only logical to suggest that Espartero's ongoing popularity owed a lot to the way in which he embodied prevailing ideas of liberal and democratic masculinity.

This brings us to perhaps the major question in historiography of $19^{\text {th }}$-century Spain: to what extent was there a shared national identity and where did it come from? The long-standing concern with the deficiencies of the Spanish state and the belief that it had produced an inadequate nationalization, especially when compared to an idealized French model, has more recently given way to a focus on culture and society and on non-state, non-elite, and regional or local agents of nationalization. This new historiography has produced a very different picture, one in which, as Fernando Molina and Miguel Cabo Villaverde describe it, «the chronology of Spanish nation building has changed substantially. The nation now appeared as a catalyst of popular affective and mobilizing loyalty earlier than was thought» (87). This analysis of the strength and persistence of the Espartero cult is very much in this methodological vein and supportive of its revisionist interpretation. If anything, with its emphasis on oral tradition and the agency of ordinary Spaniards, it pushes it even further.

Finally, this research is part of a biography of Espartero and would not have been done outside of that context. It is, in a modest way, part of the renewal of biography and illustrative of the potential of what has come to be called biographical history. The power of this approach, writes Isabel Burdiel, lies in «su capacidad para demostrar que el estudio de una trayectoria individual es una manera possible... para abordar problemas históricos sustanciales e iluminarlos con una nueva luz» (88). Along with nationalism, the role of espadones in Spain's liberal revolution, has long been one of those historical problems. As this study of the powerful and persistent Espartero cult makes clear, Espartero's role in the construction of Spanish liberalism went far beyond his actions on the battlefield or in political office. In the same way, it owed much less to Esparte-

(85) RODRÍGUEZ O (2003): 35.

(86) DudinK and HAGEMANN (2004): 7.

(87) Molina and Cabo Villaverde (2012): 66.

(88) BURDIEL (2014): 62. 
ro himself or to the political elites who created him as a hero than it did to all those Spaniards, that «coro de voces» (89), - and chorus is the appropriate word - who wrote to him, who adorned their homes with his images, who bought aleluyas and cheap biographies, who kept alive romances, and who told stories about him to their children.

\section{BIBLIOGRAFÍA}

Anguera, Pere (2003): El General Prim: Biografía de un Conspirador, Barcelona, Edhasa.

Álvarez Barrientos, JoAquín (ed.) (1977): Diccionario de la literatura popular española, Salamanca, Colegio de España.

Bellogín, Angel (1993): «Historia Contemporánea. La Gloriosa de Valladolid», en RAFAel SERRANo GARCía (ed.), La Revolución Liberal en Valladolid (1808-1868), Valladolid, Junta de Castilla y León.

Berenson, Edward (2012): Heroes of Empire: Five Charismatic Men and the Conquest of Africa, Berkeley, University of California Press.

Berenson, Edward and Gioli, Eva (2010): Constructing Charisma: Celebrity, Fame and Power in Nineteenth Century Europe, New York, Berghahn.

BERESFORD, ANDREW M. (2005): «The poetry of medieval Spain», en Cambridge History of Spanish Literature, Cambridge, Cambridge University Press, pp. 87-88.

Bermejo, Ildefonso Antonio (1875): Historia de la interinidad y guerra civil de España desde 1868, Madrid, R. Labajos, 1875.

Bermejo Martín, Francisco (2000): Espartero. Hacendado Riojano, Logroño, Instituto de Estudios Riojanos.

Birner, Angela (1995): «Los pliegos de aleluyas», en Anthropos, 166/167, pp. 117120.

BotREL, JEAN FRANÇOIS (1999): «Las historias de cordel y la historia del tiempo presente en la España del siglo XIX», en Roman populaire et/ou roman historique, Lleida, Universitat de Lleida, 1999.

- (1986): «Les 'Historias de Colportage': Essai de catalogue d'une Bibliotèque Bleue espagnole (1840-1936)», en Les Productions Populaires en Espagne, 18501920, Pau, Université de Pau, pp. 25-62.

Braudy, Leo (1997): The Frenzy of Renown, New York, Vintage.

BURDIEL, ISABEL (2014): «Historia política y biografía más allá de las fronteras», Ayer, 93, pp. 47-83.

CAIRe-MÉrida, MARIE (2006): «Teatro y Política durante el Sexenio Revolucionario», Moenia, 12, pp. 265-272.

Castelar, Emilio (1877): Discursos parlamentarios, Agustín Jubera, Madrid.

(89) Ibíd., 64. 
(1908): Correspondencia de Emilio Castelar, 1868-1898, Madrid, Sucesores de Rivadeneyra.

CAstells, Irene et al. (eds.) (2009): Heroínas y patriotas. Mujeres de 1808, Madrid, Cátedra.

Cerrillo Torremocha, Pedro C. and Martínez Rodríguez, Jesús María (eds.) (2012): Aleluyas: Juegos y literatura infantil en los pliegos de aleluyas españoles y europeos del S. XIX, Toledo, Universidad de Castilla-La Mancha.

Connell, R.W. (2005): Masculinities, Berkeley, University of California Press.

De la Fuente Monge, Gregorio (2000): Los revolucionarios de 1868, Madrid, Marcial Pons.

- (2013): «La Figura del General Espartero en el Teatro Decimonónico», Historia y Política, 29, pp.103-138.

DíAz Marín, Pedro (2008): «Espartero en entredicho. La ruina de su imagen en las elecciones de 1843», Ayer, 72, pp. 185-214.

- (2006): «La Construcción de Espartero antes de su Regencia, 1837-1840», Cuadernos de Ilustración y Romanticismo, 14, pp. 301-127.

DudinK, Stefan and Hagemann, Karen (2004): «Masculinity in Politics and War in the Age of Democratic Revolution, 1750-1850», en Dudink, Hagemann and TosH (eds.), Masculinities in Politics and War, Manchester, Manchester University Press.

Estévanez, Nicolás (1903): Fragmentos de mis memorias, Madrid, Hijos de R. Álvarez.

FINALDI, GiUSEPPE (2011): «'The Peasants did not think of Africa': empire and the Italian state's pursuit of legitimacy» en J. MACKENZIE (ed.), European empires and the people, Manchester, Manchester University Press, pp.195-228.

García Balanyà, Albert (2002): «Patria, Plebe y Política en la España Isabelina: la Guerra de África en Cataluña», en Eloy MARTín CORRALEs (ed.), Marruecos y el Colonialismo Español, 1859-1912, Barcelona, Bellaterra.

GARCía SÁNCHEZ, RAQUel (2012): «Héroe y Mártir. La construcción del mito de Diego de León», Revista de Historia Militar pp. 265-196.

Garrido Muro, Luis (2012): El Nuevo Cid: Espartero, María Cristina y el Primer Liberalismo Español, 1834-1840, Santander, Universidad de Cantabria.

GewARTH, RoBert (2005): The Bismarck Myth: Weimar Germany and the Legacy of the Iron Chancellor, New York, Oxford University Press.

Gómez URdáñez, Gracia (2005): «The Bourgeois Family in Nineteenth Century Spain: Private Lives, Gender Roles and a New Economic Model», Journal of Family History, 30, pp. 66-85.

Hidalgo, Pedro María (1866): Espartero: su historia y la de la guerra entre Don Carlos María Isidro de Borbón y su sobrina Doña Isabel II, Leon, M. González Redondo.

Hocquellet, Richard and Michonneau, StéPhane (2008): «Le heros de guerre, le militaire et la nation», Mélanges de la Casa de Velásquez, 38, pp. 95-114.

HoRne, JoHN (2004): «Masculinity in politics and war in the age of nation-states and world wars, 1850-1939», en Stefan Dudink, Karen Hagemann and John Tosh 
(eds.), Masculinities in Politics and War. Gendering Modern History, Manchester, Manchester University Press.

Hortelano, Benito (1936): Memorias de Benito Hortelano, Madrid, Espasa-Calpe.

KIERNAN, VICTOR (1966): The Revolution of 1854 in Spanish History, Oxford, Clarendon Press.

Lilti, Antoine (2014): Figures Publiques. L'invention de la célébrité, 1750-1850, Paris, Fayard.

López Mondejar, Publio (2005): Historia de la fotografía en España, Barcelona, Lunwerg, 2005.

Lyttleton, Adrian (2012): «The Hero and the People», in Silvana Patriarca and Lucy Riall (eds.), The Risorgimiento Revisited, London, Palgrave, 2012.

MARTín, LuIs (2007): «'¿Queréis recorder el Dos de Mayo?’ Estampas populares de la Guerra de la Independencia», en C. Domange (ed.), Sombras de Mayo, Madrid, Casa de Velásquez, pp. 321-344.

Molina, Fernando and Cabo Valverde, Miguel (2012): «An Inconvenient Nation: Nation Building and National identity in Modern Spain. The Historiographical Debate», in MaArten Van Ginderachter and Marnix Beyen (eds.), Nationhood from Below, ondon, Palgrave.

Morgan, Simon (2011): "Academic "Pseudo-Event" or a useful concept for historians?», Cultural and Social History, 8, pp. 95-114.

Opisso, Alfredo (1908): Semblanzas Políticas del Siglo XIX, Barcelona, J. Gili.

Palomás i Moncholí, JoAn (2004): Victor Balaguer: Renaixença, Revolució I Progres, Vilanova i La Geltru, Cep i la Nansa.

Paredes Alonso, Francisco Javier (1991): Pascual Madoz, 1805-1870: Libertad y Progreso en la Monarquía Isabelina, Pamplona, Universidad de Navarra.

Peyroux, Florencia (2011): «Familia y Política. Masculinidad y Feminidad en el Discurso Democrático Isabelino», Historia y Política, 25, pp. 149-74.

Pirala, Antonio (1875-1879), Historia contemporánea. Anales desde 1843, Madrid, M. Tello.

Riall, LuCY (2007): Garibaldi: Invention of a Hero, New Haven, Yale University Press.

RODRÍGUEZ O, JAIME E. (2003): «Los caudillos y los historiadores: Riego, Itúrbide and Santa Anna», en Manuel Chust and Victor Mínguez (eds.), La Construcción del héroe en España y México (1789-1847), Valencia, Publicacions Universitat de Valencia.

Romeo Mateo, María Cruz (2003): «Héroes y nación en el liberalismo progresista», in J.L. OlLERO, Sagasta y el progresismo liberal en España, Logroño.

SÁEz Miguel, PABlo (2011): «Espartero o el cincinato español. Historia de la candidatura a Rey del Duque de la Victoria (1868-1870)», Berceo, 160, pp. 227-260.

SHUBERT, AdRIAN (2012): «Women Warriors and National Heroes: Agustina de Aragón and her Indian Sisters», Journal of World History, 23, pp. 279-313.

Sierra, María (2012): «Política, Romanticismo y Masculinidad: Tassara (18171875)», Historia y Política, 27, pp. 203-326. 
Soubeyroux, MARIE-HÉLÈne (2000): «Histoire et mémoire au XIXe siècle: Étude de quelques biographies du Général Espartero», en JACQUES SoubEYROUX (ed.), $L a$ biographie dans le monde hispanique: XVIe-XXe siècles, Saint Etienne, Publications de la Universsité de Saint Étienne, pp. 143-156.

Thompson, Guy (2009): The Birth of Modern Politics in Spain. Democracy, Association and Revolution, 1854-1875. London, Palgrave.

Thompson, John (1995): The Media and Modernity, Stanford, Stanford University Press.

Van Ginderachter, Marten and Beyen, Marnix (2012): Nationhood from Below: Europe in the Long Nineteenth Century, London, Palgrave.

Zozaya Montes, María (2008): El casino de Madrid: Ocio, Sociabilidad, Identidad y Representación Social, Madrid, Universidad Complutense de Madrid.

Zurita Aldeguer, Rafael (2014): «El Progresismo. Héroes e Historia de la Nación Liberal» en María Cruz Romeo and María Sierra (eds.), La España Liberal, Madrid, Marcial Pons. 
